\title{
Comparison of the Prevalence and Incidence of Infection with Bovine Virus Diarrhoea Virus (BVDV) in Denmark and Michigan and Association with Possible Risk Factors
}

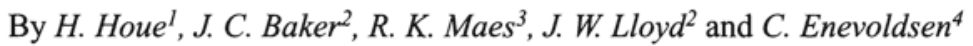

${ }^{1}$ Department of Clinical Studies, The Royal Veterinary and Agricultural University, Frederiksberg, Denmark, ${ }^{2}$ Department of Large Animal Clinical Sciences and ${ }^{3}$ Department of Microbiology, Animal Health Diagnostic Laboratory, College of Veterinary Medicine, Michigan State University, USA, and ${ }^{4}$ Department of Livestock Health and Welfare. Danish Institute of Animal Science, Foulum, Denmark.

\begin{abstract}
Houe H., J. C. Baker, R. K. Maes, J. W. Lloyd and C. Enevoldsen: Comparison of the prevalence and incidence of infection with bovine virus diarrhoea virus (BVDV) in Denmark and Michigan and association with possible risk factors. Acta vet.scand. 1995, 36, 521-531. - Based on 2 previous surveys on the occurrence of infection with bovine virus diarrhoea virus (BVDV) in Danish and Michigan dairy herds, the prevalence and incidence of the infection were compared. The presence of certain possible risk factors for the occurrence of infection in the 2 areas were summarized and it was investigated if any of these risk factors had significant effect on the presence of animals persistently infected (PI) with BVDV in the dairy herds.

Information on the cattle population density in the 2 areas was obtained from statistical yearbooks. Further information for the individual farms on age distribution, housing of animals, herd size, pasturing and purchasing policy was gathered.

The prevalence of PI animals was more than 10 times higher in Denmark as compared to Michigan. In herds without PI animals, the annual incidence of seroconversion as calculated from the age specific prevalence of antibody carriers varied in most age groups between 20-25\% in Denmark and between 5-10\% in Michigan. All investigated risk factors except for herd size were in favour of a lower prevalence of infection in Michigan. The use of having animals on pasture and at the same time having purchased more than 40 animals within recent $3 \frac{1}{2}-4$ years were significantly associated with presence of PI animals in the dairy herds $(\mathrm{p}=0.01)$ when tested by the Mantel-Haenszel $\chi^{2}$. Using multivariable logistic regression, the occurrence of PI animals was found to be significantly related to the study area (Michigan and Denmark) as well as to herd size and purchase intensity.
\end{abstract}

pestivirus; cattle; epidemiology; Denmark; USA.

\section{Introduction}

Postnatal infections with bovine virus diarrhoea virus (BVDV) are most often subclinical or only accompanied by mild transient clinical symptoms. This acute infection is followed by antibody production 2-3 weeks later (Brownlie et al. 1987). Infection of antibody negative pregnant cattle is followed by foetal infection. If foetuses are infected before day 100-120 of 
pregnancy they develop specific immunotolerance against BVDV (McClurkin et al. 1984). These animals are born persistently infected (PI) and after disappearance of colostral antibodies, virus can be detected from blood throughout their lifetime. Hence, the prevalence of BVDV infection can be expressed either as the prevalence of PI animals or the prevalence of antibody carriers. However, in areas using BVDV vaccination prevalence estimates based on antibody carriers are difficult to interpret.

There have been reports on the prevalence of viremia and persistent viremia from several countries. Examination of 3157 animals in the U.S. revealed 1.7\% PI animals (Bolin et al. 1985). In the U.K. virus was detected in $0.8 \%$ of 924 animals, but one animal could not be retested and 2 seroconverted, so a total of $0.4 \%$ proved to be persistently infected (Howard et al. 1986). Another survey from the U.K. revealed $1.8 \%$ viremic animals among 3151 animals that generally were tested as part of preventive screening programs in herds with a suspected problem with BVDV infection (Edwards et al. 1987). BVDV was detected in $0.9 \%$ of 1332 normal randomly collected cattle sera from 2 slaughterhouses in Denmark (Meyling 1984). In Sweden, examination of 711 heifers selected for artificial insemination revealed virus in $1.7 \%$ (Alenius et al. 1986). In Japan, $7.8 \%$ of 154 animals from epidemic areas showed to be persistently infected (Shimizu \& Satou 1987).

Although these surveys did not include examination of individual clinical cases, most of the surveys were more or less biased towards examinations of animals from herds with recent clinical outbreak of BVDV infection or towards selected age groups of animals. Therefore, these numbers on some occasions tend to be an overestimation of the true number of PI animals. Furthermore, due to the very different selection criteria, it is very difficult to estimate whether there are some true differences among the areas.

Only few studies have been conducted among herds without any knowledge of BVDV infection and where the herds were considered representative for the herds in the area. In Denmark one such study revealed that $53 \%$ of herds contained PI animals and that $1.4 \%$ of all cattle were PI (Houe \& Meyling 1991). Further, the annual incidence risk of infection was calculated as $34 \%$. The prevalence of herds with PI animals estimated on basis of serological spot tests were $43 \%$ (Houe 1994). Testing of all animals in 20 randomly selected dairy herds enrolled in the Dairy Herd Improvement Association in 2 counties in central Michigan revealed $0.13 \%$ PI animals among 5481 animals tested. PI animals were found in 3 of the herds (Houe et al. 1995a).

PI animals are a major source of BVDV infections (Meyling et al. 1990) and are considered of major importance in introducing the infection to susceptible herds (Roeder \& Harkness 1986) either by purchase or by contact with other cattle on pasture (Houe \& Palfi 1993). Also acutely infected animals might be a source of infection. Although direct contact between cattle is considered of major importance in spread of BVDV infections there are other sources of infection and other routes of transmission which have been outlined previously (Meyling et al. 1990, Roeder \& Harkness 1986).

The objective of this paper is to compare the prevalence and incidence of infection with BVDV in Denmark and Michigan based on the 2 previous surveys in these areas (Houe \& Meyling 1991, Houe et al. 1995a). Further, including additional not previous published information from these 2 surveys it is the purpose to compare differences in possible risk factors for the spread of infection in the 2 areas and hence, to explain the difference in prevalence and inci- 
dence observed between the 2 locations. Finally, it was determined if any of the risk factors proved to have a significant effect on the presence of PI animals in the dairy herds.

\section{Materials and methods}

\section{Data collection}

The basic information on selection of the dairy herds, the virological examination and antibody determination and information on birth dates of animals have been described in the 2 previous publications (Houe \& Meyling 1991, Houe et al. 1995a). The herd size was determined as the number of animals present at the date the herd was blood tested. In Denmark, the number of purchased animals was obtained from a database established by the Danish Institute of Animal Science. In Michigan dairy herds, information on purchased animals was obtained from a questionnaire provided to the farmers. Information on pasturing of animals was obtained from questionnaires in both areas. The data on the dairy herds are summarized in Table 1 and Table 2 .

\section{Calculations}

The incidence risk of infection was calculated from the age-specific prevalence of antibody carriers using the following formula (Lilienfeld \& Lilienfeld 1980):

$$
P_{y}=1-(1-I R)^{y}
$$

where $\mathrm{P}_{\mathrm{y}}$ is the proportion of the population that have become infected by age y (i.e. the prevalence of antibody carriers) and IR is the incidence risk. Making the calculations in age groups of 1 year, IR becomes the annual incidence risk for each age cohort of animals. For the group of animals between 1 and 2 years the age was set to 1.5 years in the formula and likewise for the other age groups. For animals older than 6 years, the age of 7 years was used in the formula. The preconditions of using this formula for BVDV infections has been described earlier (Houe \& Meyling 1991). In order to estimate incidence risk of infection from prevalence of antibody carriers it was necessary to exclude herds using vaccination. As the herds with PI animals in Michigan all had used vaccination they had to be excluded. Therefore we also excluded the Danish herds with PI animals. Thereby the calculation of incidence is based on herds without PI animals in both areas.

\section{Statistical analyses}

The effect of purchasing animals and the use of pasturing were tested by Fisher's exact test and the Mantel-Haenszel $\chi^{2}$ (stratifying on area, Michigan and Denmark). The herds were categorized as using pasturing if either young stock or cows or both cattle groups went on pasture. Logistic regression using Proc Catmod, (SAS Institute Inc 1988) was used to describe the relations between the occurrence of PI animals and potential herd level risk factors (area, herd size, pasturing of cattle and percentage of animals purchased in recent years). All variables were analysed as categorical variables. Herd size and percentage animals purchased were each categorized into 3 classes. A backward elimination strategy was applied to identify the most parsimonious yet valid model. Initially, all possible two-way product terms were included in the model. Product terms and main effects were then removed from the models until the pvalues of the differences in values of $-2 \log$ (likelihood) of the models were below 5\% at the corresponding degrees of freedom (the likelihood ratio test).

\section{Results \\ Prevalence and incidence of infection}

As previously described, the prevalences of PI 


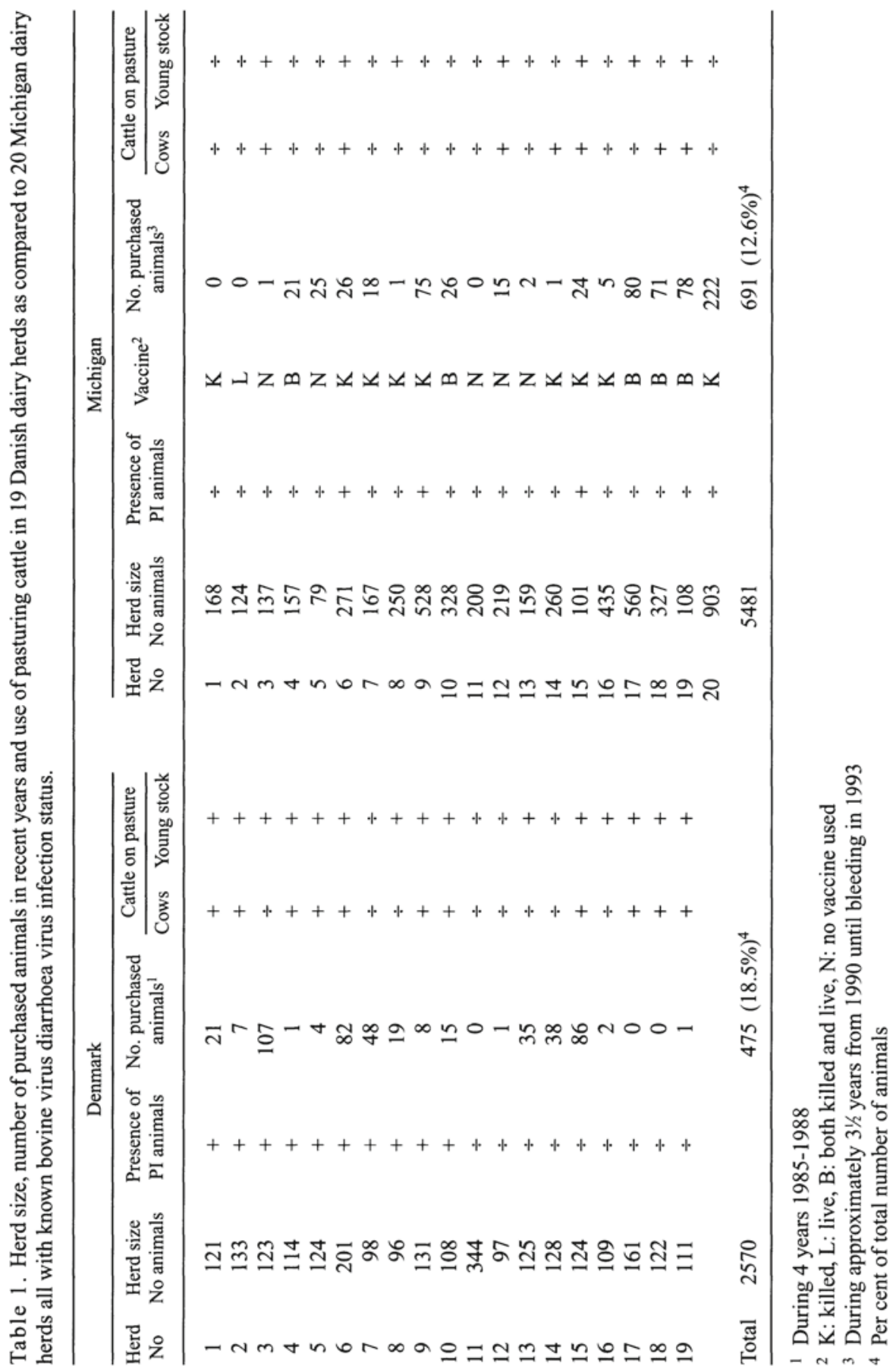


Table 2. Age distribution of animals in 19 Danish and 20 Michigan dairy herds that have been screened for bovine virus diarrhoea virus infection.

\begin{tabular}{|c|c|c|c|c|c|c|c|c|}
\hline \multirow{3}{*}{ Age (years) } & \multicolumn{4}{|c|}{ Denmark } & \multicolumn{4}{|c|}{ Michigan } \\
\hline & \multicolumn{2}{|c|}{ Total No. } & \multicolumn{2}{|c|}{ No. PI } & \multicolumn{2}{|c|}{ Total No. } & \multicolumn{2}{|c|}{ No. PI } \\
\hline & animals & $(\%)$ & animals & $(\%)^{1}$ & animals $^{2}$ & $(\%)$ & animals & $(\%)^{1}$ \\
\hline $0-1$ & 840 & 32.7 & 24 & 68.6 & 1125 & 25.3 & 4 & 57.1 \\
\hline$>1-2$ & 490 & 19.1 & 5 & 14.3 & 809 & 18.2 & 1 & 14.3 \\
\hline$>2-3$ & 430 & 16.7 & 5 & 14.3 & 685 & 15.4 & 0 & 0 \\
\hline$>3-4$ & 288 & 11.2 & 0 & 0 & 576 & 13.0 & 2 & 28.6 \\
\hline$>4-5$ & 205 & 8.0 & 0 & 0 & 389 & 8.8 & 0 & 0 \\
\hline$>5-6$ & 105 & 4.1 & 0 & 0 & 231 & 5.2 & 0 & 0 \\
\hline$>6-7$ & 50 & 1.9 & 0 & 0 & 118 & 2.7 & 0 & 0 \\
\hline$>7$ & 67 & 2.6 & 0 & 0 & 162 & 3.6 & 0 & 0 \\
\hline Age not known & 95 & 3.7 & 1 & 2.8 & 346 & 8.0 & 0 & 0 \\
\hline Total & 2570 & 100 & 35 & 100 & 4441 & 100 & 7 & 100 \\
\hline
\end{tabular}

1 Per cent of all PI animals

2 Four herds (Nos 7, 10,15 and 17) are excluded because of lack of information on age.

animals were $1.4 \%$ in Denmark and $0.13 \%$ in Michigan i.e. the prevalence was 10.8 times higher in Denmark. The age distribution of PI animals was similar between Denmark and Michigan (Table 2). In herds without PI animals and without any vaccination program, the prevalence of antibody carriers increased faster by increasing age in Danish dairy herds as compared to Michigan dairy herds (Fig. 1). The annual incidence risk of infection with BVDV as estimated from the age-specific prevalence of antibody carriers was accordingly higher in the Danish dairy herds. The incidence of infection in herds without PI animals varied in most age groups between $20-25 \%$ in Denmark and between $5-10 \%$ in Michigan (Table 3). In the age groups from 2 to 6 years, the incidence was between 1.7-5.8 times higher in Danish herds.

\section{Comparison of risk factors between}

Michigan and Denmark

Concentration of cattle in area. In the 3 counties in Denmark from which the blood samples were obtained, the total number of cat- tle was $1,011,000$ and the total number of cattle herds was 15,183 (Agricultural Statistics 1991. The 3 counties consist of $15,148 \mathrm{~km}^{2}$ (Danish Statistical Yearbook, 1991). Hence, the concentration of cattle was 67 cattle per $\mathrm{km}^{2}$ and 1.00 cattle herd per $\mathrm{km}^{2}$.

The total number of cattle in the 2 counties in Michigan was 79,000 , the total number of cattle herds was 871 and the area was $2,979 \mathrm{~km}^{2}$ (Food and Agricultural Development Statistics, 1992 and Michigan Agricultural Statistics 1993). Hence, the concentration of cattle was 27 cattle per $\mathrm{km}^{2}$ and 0.29 herd per $\mathrm{km}^{2}$ in Michigan.

Control strategy. BVDV is not a notifiable infection in either Denmark or Michigan. Control strategies are solely performed on a voluntary basis. As seen in Table 1, 15 of the 20 herds in the survey in Michigan were vaccinated. In Denmark, no vaccines against BVDV are used. Control has previously relied on follow up of disease outbreak by the veterinary practitioner. 
DENMARK

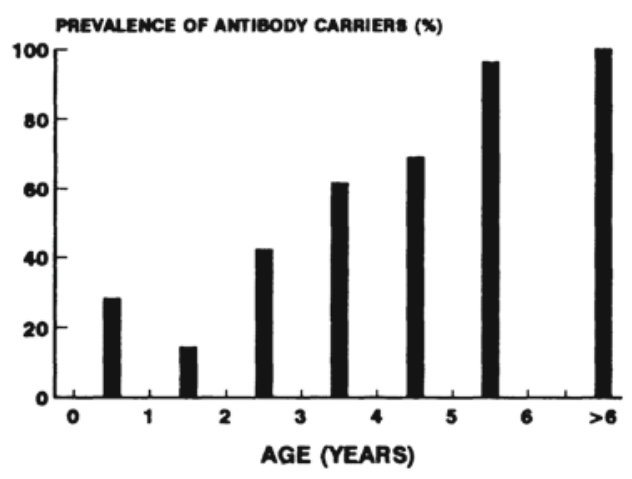

MICHIGAN

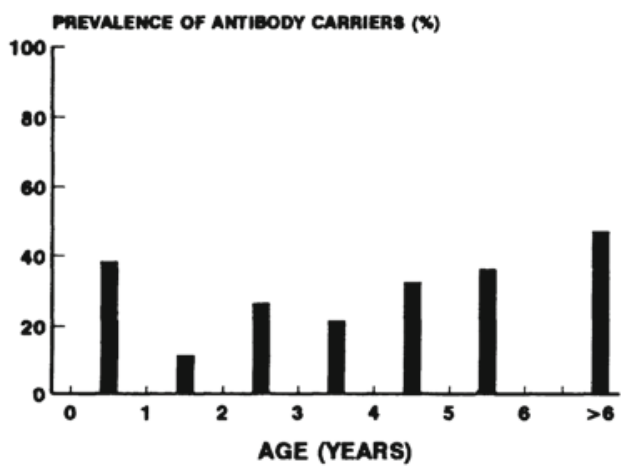

Figure 1. Age distribution of antibody carriers against bovine virus diarrhoea virus among all animals in 9 Danish dairy herds and in 5 Michigan dairy herds. Only herds without persistently infected animals are included and no vaccination was used in these herds.

Differences between Danish and Michigan dairy herds among the herds included in the study

Age distribution of animals. Table 2 compares the age distribution of the cattle in the 2 surveys. The different age distribution in the 2 areas was especially influenced by the more common practice of selling bull calves shortly after birth from Michigan dairy herds as com- pared to Danish dairy herds. Thus, there were approximately $25 \%$ less animals in the age group of 0-1 year in Michigan herds compared to Danish herds.

Housing of animals. In the 19 Danish dairy herds, all animals in each herd were housed on the same farm in buildings grouped close together. Most often different barns were built together and only separated by doors. In Michigan dairy herds, the barns were most often separated from one another. In 9 of the herds, animals were even housed on separate farms.

Herd size - pasturing - purchasing policy. The number of cattle in each herd using pasturing during the summer and the number of introduction of animals from other herds in recent years are shown in Table 1. Michigan dairy herds had approximately twice as many cattle as Danish dairy herds. Fifteen of the 19 Danish dairy herds used pasturing whereas only 9 of the 20 Michigan dairy herds used pasturing. Purchase of animals was common in both areas (Table 1).

The effect of risk factors on the presence of PI animals

In general herds with PI animals had purchased more animals in recent years compared to herds without PI animals. All herds with PI animals had purchased animals, but also most herds without PI animals had purchased animals in recent years. The effect of purchasing animals versus non-purchase of animals was not significant when each area was examined separately (Denmark: $\mathrm{p}=0.09$, Michigan: $\mathrm{p}=1.00$, Fisher's exact test, Table 4). The Mantel-Haenszel $\chi^{2}$ including both areas (stratifying on area) showed significant effect of purchasing animals $(p=0.04)$, but as the Breslow-Day test for homogeneity of the odds ratios could not be calcu- 
Table 3. Annual incidence risk of infection with bovine virus diarrhoea virus as calculated from the age-specific prevalence of antibody carriers. Nine Danish dairy herds compared to 5 Michigan dairy herds, all without presence of persistently infected animals.

\begin{tabular}{|c|c|c|c|c|c|c|c|c|}
\hline \multirow[b]{2}{*}{$\begin{array}{l}\text { Age } \\
\text { (Years) }\end{array}$} & \multicolumn{4}{|c|}{ Denmark } & \multicolumn{4}{|c|}{ Michigan } \\
\hline & $\begin{array}{l}\text { No. antibody } \\
\text { positive } \\
\text { cattle }\end{array}$ & $\begin{array}{c}\text { Total } \\
\text { no. } \\
\text { cattle }\end{array}$ & $\begin{array}{l}\text { Prevalence } \\
\text { of antibody } \\
\text { carriers } \mathrm{P}_{\mathrm{y}}\end{array}$ & $\begin{array}{l}\text { Annual } \\
\text { incidence } \\
\text { risk (IR) }\end{array}$ & $\begin{array}{l}\text { No. antibody } \\
\text { positive } \\
\text { cattle }\end{array}$ & $\begin{array}{c}\text { Total } \\
\text { no. } \\
\text { cattle }\end{array}$ & $\begin{array}{c}\text { Prevalence } \\
\text { of antibody } \\
\text { carriers } \mathrm{P}_{\mathrm{y}}\end{array}$ & $\begin{array}{l}\text { Annual } \\
\text { incidence } \\
\text { risk (IR) }\end{array}$ \\
\hline$>1-2$ & 37 & 259 & 0.14 & 0.098 & 16 & 139 & 0.12 & 0.078 \\
\hline$>2-3$ & 89 & 212 & 0.42 & 0.20 & 36 & 136 & 0.27 & 0.120 \\
\hline$>3-4$ & 94 & 153 & 0.61 & 0.24 & 17 & 80 & 0.21 & 0.066 \\
\hline$>4-5$ & 64 & 93 & 0.69 & 0.23 & 27 & 83 & 0.33 & 0.084 \\
\hline$>5-6$ & 51 & 53 & 0.96 & 0.45 & 14 & 39 & 0.36 & 0.078 \\
\hline$>6$ & 74 & 74 & 1 & 1 & 30 & 64 & 0.47 & 0.086 \\
\hline Total & 520 & 1237 & 0.42 & - & 140 & 541 & 0.26 & - \\
\hline
\end{tabular}

Table 4. The effect of purchasing animals on the presence of animals persistently infected with bovine virus diarrhoea virus.

\begin{tabular}{|c|c|c|c|c|c|c|}
\hline & \multicolumn{3}{|c|}{ Denmark $^{1}$ (No. of herds) } & \multicolumn{3}{|c|}{$\operatorname{Michigan}^{2}$ (No. of herds) } \\
\hline & $\begin{array}{c}\text { With } \\
\text { PI animals }\end{array}$ & $\begin{array}{c}\text { Without } \\
\text { PI animals }\end{array}$ & Total & $\begin{array}{c}\text { With } \\
\text { PI animals }\end{array}$ & $\begin{array}{l}\text { Without } \\
\text { PI animals }\end{array}$ & Total \\
\hline Purchase & 10 & 6 & 16 & 3 & 14 & 17 \\
\hline No Purchase & 0 & 3 & 3 & 0 & 3 & 3 \\
\hline Total & 10 & 9 & 19 & 3 & 17 & 20 \\
\hline
\end{tabular}

${ }^{1} \mathrm{p}=0.09$ (Fisher's exact test) ${ }^{2} \mathrm{p}=1.00$ (Fisher's exact test)

Summary statistics: Mantel-Haenszel $\chi^{2}$ (stratifying on area) $=4.09, \mathrm{df}=1, \mathrm{P}=0.04$.

Breslow-Day test for homogeneity of the odds ratios was not computed by SAS because the data were too sparse.

Table 5. The effect of pasturing animals on the presence of animals persistently infected with bovine virus diarrhoea virus.

\begin{tabular}{|c|c|c|c|c|c|c|}
\hline & \multicolumn{3}{|c|}{ Denmark $^{1}$ (No. of herds) } & \multicolumn{3}{|c|}{ Michigan $^{2}$ (No. of herds) } \\
\hline & $\begin{array}{c}\text { With } \\
\text { PI animals }\end{array}$ & $\begin{array}{l}\text { Without } \\
\text { PI animals }\end{array}$ & Total & $\begin{array}{c}\text { With } \\
\text { PI animals }\end{array}$ & $\begin{array}{l}\text { Without } \\
\text { PI animals }\end{array}$ & Total \\
\hline Pasturing & 9 & 6 & 15 & 2 & 7 & 9 \\
\hline No Pasturing & 1 & 3 & 4 & 1 & 10 & 11 \\
\hline Total & 10 & 9 & 19 & 3 & 17 & 20 \\
\hline
\end{tabular}

${ }^{1} \mathrm{p}=0.30$ (Fisher's exact test) ${ }^{2} \mathrm{p}=0.57$ (Fisher's exact test)

Summary statistics: Mantel-Haenszel $\chi^{2}$ (stratifying on area) $=2.06, \mathrm{df}=1, \mathrm{P}=0.15$.

Breslow-Day test for homogeneity of the odds ratios: $\chi^{2}=0.06, \mathrm{df}=1, \mathrm{P}=0.80$. 
Table 6. The effect of either pasturing animals or having purchased at least 40 animals within $31 / 2-4$ years or both on the presence of animals persistently infected with bovine virus diarrhoea virus.

\begin{tabular}{lrrrrrrrrr}
\hline & \multicolumn{3}{c}{ Denmark' (No. of herds) } & & & \multicolumn{3}{c}{ Michigan ${ }^{2}$ (No. of herds) } \\
\cline { 2 - 3 } & $\begin{array}{c}\text { With } \\
\text { PI animals }\end{array}$ & $\begin{array}{c}\text { Without } \\
\text { PI animals }\end{array}$ & Total & & $\begin{array}{c}\text { With } \\
\text { PI animals }\end{array}$ & $\begin{array}{c}\text { Without } \\
\text { PI animals }\end{array}$ & Total \\
\hline Pasturing and $/$ or $>=40$ purchase & 10 & 6 & 16 & & 3 & 8 & 11 \\
No Pasturing and $<40$ purchase & 0 & 3 & 3 & & 0 & 9 & 9 \\
Total & 10 & 9 & 19 & & 3 & 17 & 20 \\
\hline
\end{tabular}

${ }^{1} \mathrm{p}=0.09$ (Fisher's exact test) ${ }^{2} \mathrm{p}=0.22$ (Fisher's exact test)

Summary statistics: Mantel-Haenszel $\chi^{2}$ (stratifying on area) $=6.45, \mathrm{df}=1, \mathrm{P}=0.01$.

Breslow-Day test for homogeneity of the odds ratios was not computed by SAS because the data were too sparse.

lated, interaction with area cannot be excluded. Pasturing of animals did not show significant effect on the presence of PI animals (Table 5), but the effect of either using pasturing or having purchased more than 40 animals in recent $31 / 2-4$ years or both was highly significant $\left(\chi^{2}=\right.$ $6.45, \mathrm{df}=1, \mathrm{p}=0.01$, Table 6 ), however interaction with area cannot be excluded.

Logistic regression. The best model to describe the data included the variables area, herd size and percentage of purchased animals and the product of herd size and percentage of purchased animals. Occurrence of PI animals was significantly related to the study area, Michigan and Denmark $(\mathrm{p}<0.001)$ as well as to the product of herd size and purchase intensity (interaction, $\mathrm{p}<0.01$ ) when these terms were tested by backward elimination from the model. By interaction is understood that the relation between PI occurrence and purchase intensity differed according to herd size. Use of pasture was not a statistically significant risk factor.

\section{Discussion}

This comparative study showed that PI animals were 10 times more prevalent in Denmark as compared to Michigan. Also when the inci- dence of infection was compared, cattle in Denmark demonstrated higher risk of infection. The incidence of infection showed a tendency to higher risk among older animals compared to younger animals in the Danish herds. It could be speculated that an increase in prophylactic measures against BVDV infections in recent years had reduced the incidence of infection and thus created an age specific cohort effect. However, as the annual incidence risk of infection did not vary among age groups when all Danish dairy herds were included (Houe \& Meyling 1991), the variation among age groups in this study is believed to be due to random variation. Thus, herds without PI animals show large variation in the age specific prevalence of antibody carriers (Houe 1992).

The difference in prevalence between Michigan and Denmark is also comparable to the difference in virus isolations from abortions submitted to the veterinary diagnostic laboratories. Among 1,208 aborted and stillborn foetuses from Michigan, Wisconsin, Indiana, Ohio and Minnesota examined from 1983 to 1994 , BVDV was isolated from 9 foetuses $(0.74 \%)$ (Yamini et al. submitted). Among 805 abortions in Denmark examined from 1986 to 1988 , BVDV was isolated from 39 (4.8\%) (Meyling et al. 1990). 
The widespread use of vaccines in Michigan would an obvious explanation of the lower prevalence of infection in Michigan. However, there are many additional circumstances to be in favour of a lower prevalence of infection in Michigan: The concentration of cattle and cattle herds are lower and pasturing are used to a lesser extent in Michigan. Therefore the possibilities of direct animal to animal contact between cattle from different herds is lower in Michigan. Transmission of infection within herds is also less likely in Michigan because young stock often are housed on separate farms. As most PI animals were found among the young stock, the transmission from these to pregnant animals in the cow barn will be reduced. Further, the common practice of selling bull calves shortly after birth from Michigan dairy herds will reduce the number of PI animals in these herds.

Unfortunately, there seem to be too many different factors involved in order to judge how much of the lesser infection in Michigan can be ascribed the various parameters.

Purchase of animals and, in particular, the combination of pasturing and purchase of animals had significant effect on the presence of PI animals when tested by Mantel-Haenszel $\chi^{2}$. However, interaction between the areas could not be excluded. These calculations show the difficulty of combining data from 2 areas. Logically, the effect of risk factors will be different for different areas. For example, pasturing of cattle is much more risky in Denmark compared to Michigan because the concentration of animals is much higher and because the prevalence of infected herds is higher in Denmark. The higher prevalence of PI animals in Denmark will also make purchase of animals a more important determinant in this country. Using logistic regression, a significant effect of area as well as herd size and purchase intensity was found. In the model, use of pasture was not a statistically significant risk factor. However, it is not biologically plausible that use of pasture is unrelated to the occurrence of PI animals. An explanation to this finding could be that the use of pasture was so strongly related to herd size and purchase intensity, that the true relationship was not revealed in the model. From the study there is no obvious explanation of the interaction between purchase intensity and herd size. One may speculate that some of the interaction is due to a self limiting effect of BVDV infections: if the risk of infection get very high most animals acquires antibodies and thus the likelihood of PI animals in the near future will decrease.

More precise determination on the importance of various risk factors will require a larger number of herds than was available in this study.

A potential bias in this study is the use of presence of PI animals for assessing the risk factors. PI animals can stay in the herds for several years and the exact time of the introduction of infection from an outside source is therefore difficult to determine. It would therefore be an advantage to perform studies on risk factors as cohort studies in stead of cross-sectional studies.

Different methods of herd surveillance such as polymerase chain reaction for detection of BVDV in bulk milk (Brock \& Radwan 1993) and serological screening test of young stock (Houe 1992, Houe 1994, Houe et al. 1995b) may be useful for obtaining a herd diagnosis and hence suitable for examination of risk factors on a larger scale in the future.

\section{References}

Agricultural Statistics 1990, Danmarks Statistik, Copenhagen, $256 \mathrm{pp}$.

Alenius S, Jacobsen S-O, Cafaro E: Frequency of bovine viral diarrhea virus infections in Sweden among heifers selected for artificial insemina- 
tion. Proc. World Congr. Diseases of Cattle. 1986, 14, 204-207.

Bolin SR, McClurkin AW, Coria MF: Frequency of persistent bovine viral diarrhea virus infection in selected cattle herds. Amer. J. vet. Res. 1985, 46, 2385-2387.

Brock KV, Radwan GS: Detection of bovine viral diarrhea virus in bulk milk samples by PCR amplification. In: Edwards S (ed): Proceedings of the Second Symposium on pestiviruses 1-3 October 1992. 1993, 223-226.

Brownlie J, Clarke MC, Howard CJ, Pocock DH: Pathogenesis and epidemiology of bovine virus diarrhoea virus infection of cattle. Annls. Rech. vét. 1987, 18, 157-166.

County Food and Agricultural Development Statistics, 1992, Michigan Department of Agriculture, Lansing, Michigan.

Danish Statistical Yearbook, 1991, Danmarks Statistik Copenhagen, $575 \mathrm{pp}$.

Edwards S, Drew TW, Bushnell SE: Prevalence of bovine virus diarrhoea virus viraemia. Vet. Rec. 1987, 120, 71.

Houe H: Serological analysis of a small herd sample to predict presence or absence of animals persistently infected with bovine viral diarrhoea virus (BVDV) in dairy herds. Res. Vet. Sci. 1992, 53, 320-323.

Houe $H$ : Bovine virus diarrhoea virus: detection of Danish dairy herds with persistently infected animals by means of a screening test of ten young stock. Prev. Vet. Med. 1994, 19, 241-248.

Houe H, Baker JC, Maes RK, Ruegg PL, Lloyd JW: Application of antibody titers against bovine viral diarrhea virus (BVDV) as a measure to detect herds with presence of cattle persistently infected with BVDV. J. Vet. Diag. Invest. 1995b, 7, 327332.

Houe H, Baker JC, Maes RK, Wuryastuti H, Wasito $R$, Ruegg PL, Lloyd JW: Prevalence of cattle persistently infected with bovine viral diarrhea virus in 20 dairy herds in two counties in central Michigan and comparison of prevalence of antibody positive cattle among herds with different infection and vaccination status. J. Vet. Diag. Invest. 1995a, 7, 321-326.

Houe H, Meyling A: Prevalence of bovine virus diarrhoea (BVD) in 19 Danish dairy herds and estimation of incidence of infection in early pregnancy. Prev. Vet. Med. 1991, 11, 9-16.

Houe H, Palfi V: Estimation of herd incidence of infection with bovine virus diarrhoea virus
(BVDV) in herds previously without animals persistently infected with BVDV. Acta vet. scand. 1993, 34, 133-137.

Howard CJ, Brownlie J, Thomas LH: Prevalence of bovine virus diarrhoea virus viraemia in cattle in the UK. Vet. Rec. 1986, 119, 628-629.

Lilienfeld AM, Lilienfeld DE: Foundations of epidemiology. Oxford University Press, New York, 1980, $375 \mathrm{pp}$.

McClurkin AW, Littledike ET, Cutlip RC, Frank GH, Coria MF, Bolin SR: Production of cattle immunotolerant to bovine viral diarrhea virus. Can. J. Comp. Med. 1984, 48, 156-161.

Meyling A: Detection of BVD virus in viremic cattle by an indirect immunoperoxidase technique. In: (eds.). McNulty MS, MacFerrari JB. Recent advances in virus diagnosis. Martinus Nijhoff Publishers, Boston. 1984, 37-46.

Meyling A, Houe H, Jensen AM: Epidemiology of bovine virus diarrhoea virus. Rev. sci. tech. Off. int. Epiz. 1990, 9, 75-93.

Michigan Agricultural Statistics, 1993, Michigan Department of Agriculture, Lansing, Michigan, $89 \mathrm{pp}$.

Roeder PL, Harkness JW: BVD virus infection: Prospects for control. Vet. Rec. 1986, 118, 143-147.

SAS Institute Inc. SAS STAT ${ }^{\mathrm{TM}}$ Users Guide, Release 6.03 Edition Cary, NC: SAS Institute Inc., 1988,1928 pp.

Shimizu M, Satou K: Frequency of persistent infection of cattle with bovine viral diarrhea-mucosal disease virus in epidemic areas. Jpn. J. Vet. Sci. 1987, 49, 1045-1051.

Yamini B, Mullaney TP, Trapp, AL: Causes of abortion in bovine: 1208 cases (1983-1994). J. Vet. Diag. Invest. (Submitted for publication).

\section{Sammendrag}

Sammenligning af pravalensen og incidensen af infektion med bovin virusdiarré virus (BVDV) $i$ Danmark og Michigan og sammenhang med mulige risikofaktorer

Baseret på to tidligere undersøgelser over forekomsten af infektion med bovin virusdiarré virus (BVDV) i malkekvægsbesætninger i Danmark og Michigan blev der foretaget en sammenligning af prævalensen og incidensen af infektionen mellem de to områder. Tilstedeværelsen af mulige risikofaktorer 
for forekomst af infektion blev opsummeret, og det blev undersøgt, hvorvidt nogle af disse risikofaktorer havde signifikant indflydelse på forekomst af persistent inficerede (PI) dyr i besætningerne.

Data vedrørende populationstætheden af kvæg i de to områder blev indsamlet fra statistiske årbøger. Herudover blev der fra hver enkel besætning indsamlet oplysninger om aldersfordeling, opstaldning af dyr, besætningsstørrelse, brug af sommergræsning samt indkøb af dyr.

Prævalensen af PI-dyr var mere end 10 gange højere i Danmark sammenlignet med Michigan. I besætninger uden PI-dyr blev den årlige incidens af serokonverteringer beregnet ud fra den aldersspecifikke prævalens af antistofpositive dyr. Incidensen varierede i de fleste aldersgrupper mellem $20-25 \%$ i Danmark sammenlignet med 5-10\% i Michigan.

Alle undersøgte risikofaktorer undtagen besætningsstørrelse ville befordre en lavere prævalens af infektionen i Michigan. Ved anvendelse af MantelHaenszel $\chi^{2}$ vistes brug af sommergræsning samtidig med, at der var indkøbt over 40 dyr indenfor de seneste $31 / 2-4$ år, at have signifikant effekt på forekomst af PI-dyr i besætningerne $(\mathrm{p}=0.01)$. Ved anvendelse af multipel logistisk regression fandtes forekomsten af PI-dyr at være signifikant relateret til undersøgelsesområde (Michigan og Danmark), besætningsstørrelse og indkøbsintensitet.

(Received July 18, 1995; accepted August 18, 1995).

Reprints may be obtained from: H. Houe, Department of Clinical Studies, The Royal Veterinary and Agricultural University, Bülowsvej 13, DK-1870 Frederiksberg C, Denmark. 
